\title{
Nutrient constituents of some samples of shelled roasted kernel of oil palm (Elaeis guineensis) from Ghana
}

\author{
E. K. ANKRAH \\ Food Research Institute, CSIR, P. O. Box M. 20, Accra, Ghana
}

SUMMARY

The nutrient contents of samples of shelled roasted kernel of oil palm (Elaeis guineensis) were evaluated by determining the proximate composition, free fatty acids, and mineral contents. The samples contained 8.7 per cent moisture, 50.1 per cent fat. 9.9 per cent protein, 1.2 per cent ash, and 3.8 per cent free fatty acids (calculated as lauric acid). The calcium and phosphorus contents were 346 and $567 \mathrm{mg}$ per 100 dry sample, respectively.

Research and development note. Received 29 Sep 97; revised 18 Jun 98 .

\section{Introduction}

In Ghana, the kernel nut of oil palm (Elaeis guineensis) is either manually or mechanically cracked, roasted, and milled before the extraction of the palm kernel oil. The palm kernel oil is one of the most used of the lauric acid group of oils, containing a high level of saturated fatty acids such as lauric (45-55 per cent) and myristic (14-20 per cent). Because it has a low degree of unsaturation (11-28 per cent), the oil possesses a high oxidative stability (Young, 1983). In Ghana, palm kernel oil is used for cooking and frying. The cake obtained after extracting the oil from the kernel is used to formulate animal feed.

This study determines the nutrient composition af the shelled roasted palm kernel. It also seeks to provide the miller with information on the oil content of the roasted palm kernel.

Materials and methods

Samples of shelled roasted kernet of oil palm

\section{RÉSUMÉ}

ANKRAH, E. K.: Les constituants nutritifs de queques échantillons d'amainde décortiqué rôti du palmier (Elaeis guineensis) de Ghana. Les contenus nutritifs des échantillons d'amande décortiqué rôti du palmier (Elaeis guineensis) étaient évalués en déterminant la constitution immédiate, les acides gras libres et les conenus minéraux. Les échantillons contenaient 8.7 pour cent d'humidité, 50.1 pour cent de graisse, 9.9 pour cent de protéine, 1.2 pour cent de cendre, et 3.8 pour cent de acides gras libres (calculés en tant qu'acide laurique). Les contenus de calcium et de phosphore étaient $346 \mathrm{mg}$ et $567 \mathrm{mg}$ respectivement par $100 \mathrm{~g}$ d'échantillon sec.

(Elaeis guineensis) were collected from Bubuashie in Accra, Tema, and Takoradi. The samples were ground in laboratory grinder before they were analysed.

The moisture, fat, protein, ash, and free fatty acids contents were determined according to the methods described by Pearson (1976).

Calcium was determined according to a slightly modified method of the AOAC (1984) while phosphorus was measured according to the method described by Fogg \& Wilkinson (1958).

\section{Results and discussion}

Table 1 shows the chemical composition of the samples. The figures were compared with values for palm kernel reported by Hartley (1988). The samples contained a mean of 50.1 per cent fat with range of 48.3 to 52.6 per cent compared with range of 47 to 52 per cent reported by Hartley (1988).

Factors for judging palm kernel included the free fatty acid content of the oil and the moisture 
TABLE 1

Chemical Composition of Samples of Shelled Roasted Palm Kernel from Ghana

\begin{tabular}{lccccccc}
\hline $\begin{array}{l}\text { Name of } \\
\text { sample }\end{array}$ & $\begin{array}{c}\text { Moisture } \\
(\%)\end{array}$ & $\begin{array}{c}\text { Fat } \\
(\%)\end{array}$ & $\begin{array}{c}\text { Protein } \\
(\%)\end{array}$ & $\begin{array}{c}\text { Free fatty } \\
\text { acids (as } \\
\text { lauric acid) } \\
(\%)\end{array}$ & $\begin{array}{c}\text { Ash } \\
(\%)\end{array}$ & $\begin{array}{c}\text { Calcium } \\
(\mathrm{mg} / 100 \mathrm{~g})\end{array}$ & $\begin{array}{c}\text { Phosphorus } \\
(\mathrm{mg} / 100 \mathrm{~g})\end{array}$ \\
\hline Shelled roasted palm kernel & 8.7 & 50.1 & 9.9 & 3.8 & 1.2 & 346 & 567 \\
& $(5)$ & $(5)$ & $(2)$ & $(5)$ & $(5)$ & $(5)$ & $(5)$ \\
& $6.5-11.3$ & $48.3-52.6$ & $9.6-10.3$ & $1.9-6.1$ & $1.9-2.0$ & $304-404$ & $473-680$ \\
Palm kernel* & $6-8$ & $47-52$ & $7.5-9.0$ & $3-7$ & 2 & - & - \\
\hline
\end{tabular}

The figures represent mean and range values

Figures in parenthesis denote the number of samples

*According to Hartley, C.W.S. (1988)

level of the kernel (Hartley, 1988). The samples contained mean of 3.8 per cent free fatty acids (as lauric acid) compared with reported range of 3 to 7 per cent for kernels arriving in importing countries, and mean of 8.7 per cent moisture compared with reported range of 6 to 8 per cent. The roasted palm kernel was also found to contain a mean of 9.9 per cent protein compared with known range of 7.5 to 9.0 per cent, and 1.2 per cent ash compared with a reported value of 2 per cent. The roasted palm kernel also contained means of $346 \mathrm{mg}$ calcium and $567 \mathrm{mg}$ phosphorus per $100 \mathrm{~g}$ sample.

No information was obtainable as to whether the roasted palm kernel samples analysed were of the local, hybrid, or mixed types. Data on the storage conditions, roasting temperature, and time were also unavailable.

\section{Acknowledgement}

The author greatly appreciates the technical assistance of the staff of the Chemistry Section of the Food Research Institute.

\section{REFERENCES}

AOAC (1984) Official methods of analysis, 14th ed. Washington DC, Association of Official Analytical Chemists.

Fogg, D. N. \& Wilkinson, N. T. (1958) The colorimetric determination of phosphorus. Analyst, Lond. 83, 406-414.

Hartley, C. W.S. (1988) The oil palm (Elaeis guineensis Jacq), 3rd ed. Tropical Agriculture Series. UK, Longman Scientific and Technical.

Pearson, D. (1976) The chemical analysis of foods. 7 th ed. Edinburgh, London, Churchill Livingstone.

Young, F. V. K. (1983) Palm kernel and coconut oils: Analytical characteristics, process technology and uses. J. Am. Oil Chem. Soc. 60 (2), 374-379. 